\title{
IDENTYFIKACJA RYZYKA WYNIKAJĄCEGO Z WPŁYWU INTERESARIUSZY NA REALIZACJĘ INWESTYCJI KOLEJOWYCH W POLSCE
}

\author{
Jan Kowalski ${ }^{\bowtie}$, Mieczysław Połoński \\ Wydział Budownictwa i Inżynierii Środowiska, Szkoła Główna Gospodarstwa Wiejskiego w Warszawie, Warszawa
}

\begin{abstract}
STRESZCZENIE
Procedura realizacji inwestycji kolejowych w Polsce jest czasochłonna, bardzo złożona i obarczona wieloma czynnikami ryzyka. Konieczne jest zatem poprawienie poziomu zarządzania ryzykiem na planowanych inwestycjach kolejowych. Celem szerszego rozpoznania czynników ryzyka autorzy w artykule przedstawiają propozycję własnej metody analizy interesariuszy i identyfikacji ryzyka $\mathrm{z}$ nimi związanego. W artykule przedstawiono również przykład analizy siły wpływu poszczególnych grup interesariuszy na badaną inwestycję, w tym na bazowy harmonogram prac. Analiza interesariuszy przedstawiona w artykule wskazuje na ich znaczący wpływ na inwestycje kolejowe oraz konieczność uwzględnienia ich oczekiwań podczas planowania nowych przedsięwzięć.
\end{abstract}

Słowa kluczowe: interesariusze, identyfikacja zagrożeń, ryzyko, inwestycje kolejowe, planowanie przedsięwzięć budowlanych

\section{WSTĘP}

Jak podano w źródłach (Latawiec, 2016; Połoński i Kowalski, 2016, 2017), zarządzanie inwestycjami kolejowymi w Polsce jest złożonym procesem inwestycyjnym, który swoim odziaływaniem obejmuje wiele podmiotów, w tym również interesariuszy. Jednym z wyzwań podczas planowania i realizacji inwestycji kolejowych jest docenienie roli interesariuszy (ang. stakeholders) i ich wpływu na funkcjonowanie przedsięwzięć kolejowych. Przemyślany plan działania i odpowiednie kroki zaradcze już na etapie planowania mogą zniwelować przyszłe perturbacje inwestycyjne. Identyfikacja interesariuszy oraz dogłębna analiza ich oczekiwań i potrzeb, m.in. jako przyszłych właścicieli, użytkowników czy zarządców tych inwestycji, powinna więc być fundamentalnym elementem budowania strategii planowania i realizacji przedsięwzięć inwestycyjnych, w tym przedsięwzięć kolejowych.

Konieczność analizy interesariuszy i ich wpływu na poszczególne procesy inwestycji nie wynika z przepisów obowiązującego prawa, a jedynie ze strategii menedżera danego przedsięwzięcia. Należy zaznaczyć, że wiele zespołów i menedżerów odpowiedzialnych za realizację przedsięwzięć takiej analizy nie dokonuje, co może doprowadzić do dotkliwych konsekwencji. Warto podkreślić, że jak pisze Łukasiewicz (2012), zagadnienia związane z zarządzaniem interesariuszami są nowością w polskiej rzeczywistości gospodarczej, zaś ich zasięg ze względu na czynniki zewnętrzne (np. regulacje UE) jest szeroki i społecznie bardzo istotny.

\footnotetext{
凶jan_kowalski@sggw.pl
} 
Nie ulega wątpliwości, że na terenie Polski mamy do czynienia z coraz większą wiedzą interesariuszy na temat instrumentów prawnych pozwalających wpływać na sposób planowania i realizacji przedsięwzięć kolejowych. Przy ich użyciu mogą oni (zwłaszcza interesariusze zewnętrzni) np. opóźniać inwestycję, wpłynąć na wybór jej lokalizacji, doprowadzić do wstrzymania jej realizacji albo nie dopuścić do jej rozpoczęcia. Często w ramach danego projektu niezbędna jest dodatkowa osoba odpowiedzialna za kontakty $\mathrm{z}$ interesariuszami (zarówno instytucjonalnymi, jak i np. poszczególnymi grupami społecznymi), która zadba o utrzymanie prawidłowych relacji z nimi, troszcząc się przy tym o niwelowanie zagrożeń i likwidowanie konfliktów.

W artykule przedstawiono proponowaną przez autorów metodę zwiększenia efektywności procesu inwestycyjnego przyszłych inwestycji kolejowych poprzez identyfikację ich interesariuszy oraz grup ryzyka z nimi związanego.

\section{MATERIAt I METODY}

\section{Interesariusze przedsięwzięcia kolejowego}

W ramach nowoczesnego podejścia do zarządzania projektami interesariusze coraz częściej są angażowani w procesy przedsięwzięć budowlanych na każdym etapie realizacji. W modelach zarządzania projektami (OGC, 2006; PMI, 2009) uwzględnia się zaangażowanie i/lub zainteresowanie poszczególnych interesariuszy realizacją projektu oraz to, że ich potrzeby i wymagania mogą pozytywnie lub negatywnie wpływać na jego rezultat (Forum Kolejowe, 2012).

Pojęcie stakeholders - interesariusze po raz pierwszy zostało użyte w 1963 roku przez pracowników Stanford Research Institute. Znaczący wzrost zainteresowania komunikacją społeczną w krajach rozwiniętych, szczególnie w Europie Zachodniej, Australii, Kanadzie czy USA, notuje się od lat 80. XX wieku, kiedy to została wydana fundamentalna w tym względzie praca Edwarda Freemana Strategic Management: A Stakeholder Approach (Łukasiewicz, 2012). Publikacja ta zaprezentowała nowe spojrzenie biznesowe na interesariuszy, a szczególnie na ich wpływ na otoczenie.

Często poszczególne grona interesariuszy są określane mianem strategicznych partnerów i wskazuje się je jako osoby bądź grupy, które wywierają bezpośredni lub pośredni wpływ na dany etap inwestycji. Najczęściej jednak interesariuszy definiuje jako instytucje i organizacje, które spełniają dwa warunki: po pierwsze są zainteresowane działaniem firmy, jej decyzjami i efektami działalności; po drugie są w stanie wywrzeć efektywną presję na organizację (Obłój, 1998; Romanyuk, 2017). Autorzy w ramach niniejszych badań, w podobny sposób jak Freeman (Łukasiewicz, 2012), charakteryzują interesariuszy inwestycji kolejowych jako: wewnętrznych związanych bezpośrednio z realizacją kontraktu i zewnętrznych oraz indywidualnych i grupowych (rys. 1). Podział ten daje każdemu interesariuszowi (osobie, jednostce, grupie) możliwość wpływu na dane przedsięwzięcie w części lub całości, co w przyszłości powinno implikować konieczność wbudowania roli poszczególnych interesariuszy w procesy przygotowania i realizacji kolejowych przedsięwzięć budowlanych.

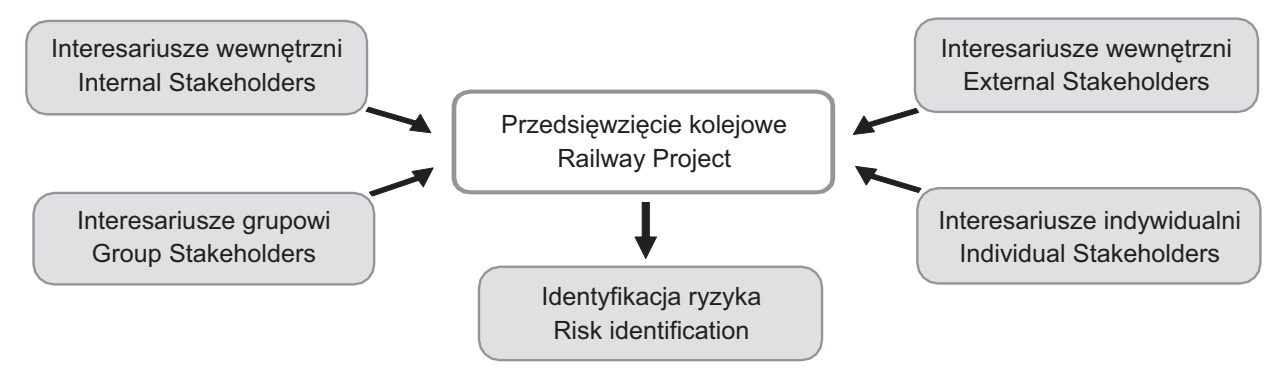

Rys. 1. Grupy interesariuszy przedsięwzięcia kolejowego

Fig. 1. Group of stakeholders of the railway project 
Kowalski, J., Połoński, M. (2017). Identyfikacja ryzyka wynikającego z wpływu interesariuszy na realizację inwestycji kolejowych w Polsce. Acta Sci. Pol. Architectura, 16 (4), 83-92. doi: 10.22630/ASPA.2017.16.4.08.

\section{Opis badania i obiektu}

Przykładowa identyfikacja interesariuszy oraz ryzyka z nimi związanego została opracowana w ramach szerzej zakrojonych badań na podstawie danych z realizacji wybranego kontraktu kolejowego. Skrócony przebieg proponowanej metody przedstawiono na rysunku 2 .

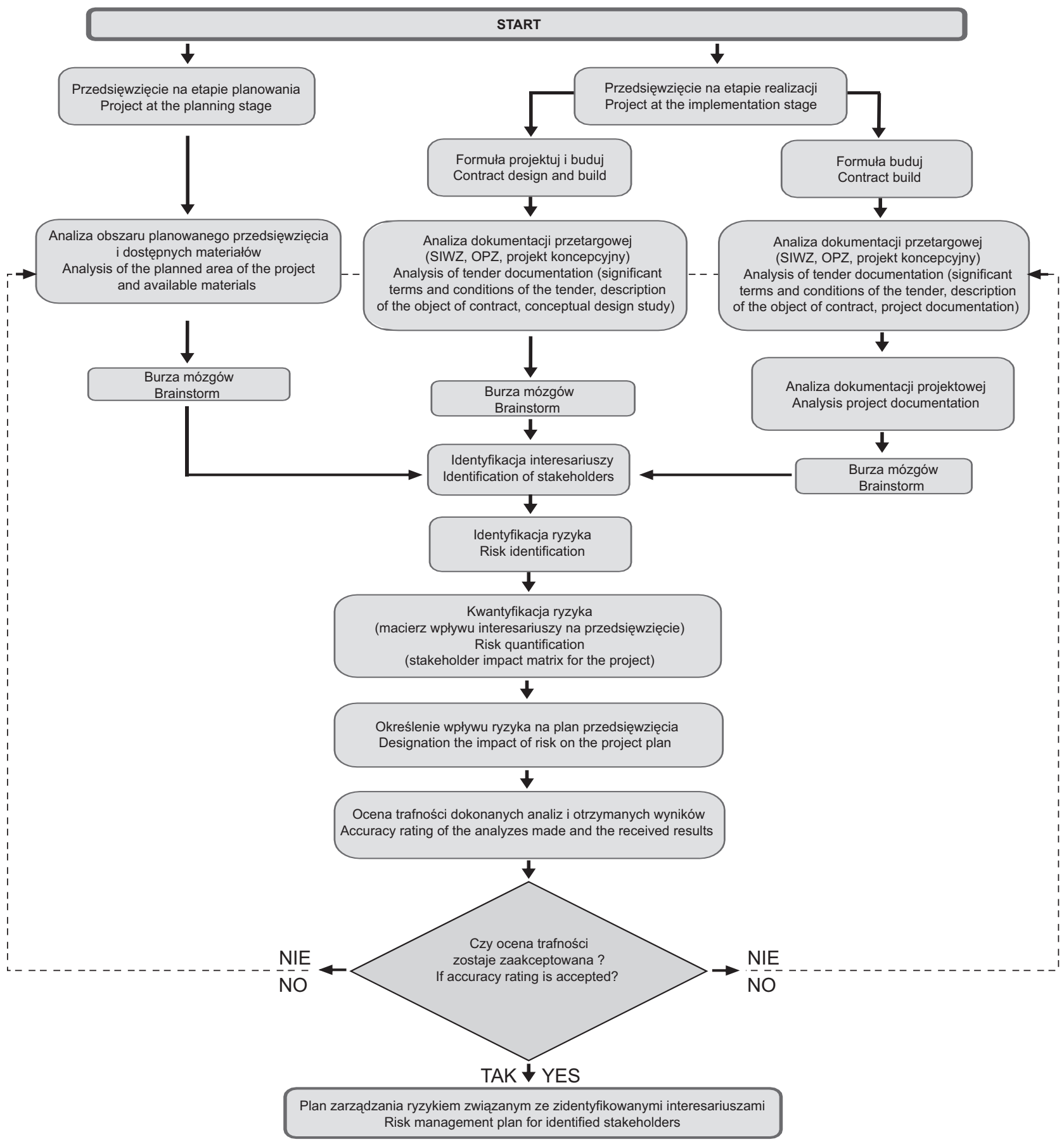

Rys. 2. Schemat identyfikacji interesariuszy $\mathrm{i}$ ich wpływu na przedsięwzięcie kolejowe

Fig. 2. A diagram for identification of stakeholders and their impact on a railway project 
Zakres prac na analizowanym obiekcie obejmował modernizację trzech stacji kolejowych oraz wybranych odcinków szlakowych między tymi stacjami, na liniach kolejowych należących i użytkowanych przez PKP PLK SA. Inwestorem realizowanego kontraktu był PKP PLK SA, a wykonawcą konsorcjum czterech zagranicznych firm. Badany obiekt jest zlokalizowany na terenie dwóch sąsiednich województw. Całkowita kwota kontraktu brutto wynosiła ok. $525 \mathrm{mln}$ PLN, a planowany termin realizacji prac wynosił 35 miesięcy (1065 dni). Biorąc pod uwagę położenie, zasięg i znaczenie modernizowanego odcinka, należało spodziewać się znaczącego wpływu poszczególnych grup interesariuszy. Zostało to potwierdzone w dalszych badaniach.

Pozyskane informacje z przeprowadzonej kwerendy dokumentów posłużyły do identyfikacji interesariuszy podczas zastosowanej heurystycznej metody - burzy mózgów. Klasyfikację interesariuszy przeprowadzono zgodnie z propozycją podziału na grupy według rysunku 1. Następnie dokonano specyfikacji możliwych czynników ryzyka. W dalszej kolejności opracowano macierz wpływu poszczególnych interesariuszy na dane przedsięwzięcie. Zobrazowano również ich wpływ na bazowy harmonogram prac.

$\mathrm{Na}$ koniec tych badań zdaniem autorów artykułu należy ocenić w grupie ekspertów, czy wyniki przeprowadzonej analizy mogą zostać uznane za prawidłowe. Jeżeli końcowa weryfikacja potwierdzi poprawność wyników, należy opracować końcowy plan zarządzania ryzykiem (plan ten nie jest przedmiotem niniejszego artykułu). Jeżeli natomiast powstaną wątpliwości w stosunku do wyników analiz, proces identyfikacji należy przeprowadzić od początku.

Poszczególne kroki badania uzależnione od etapu cyklu inwestycyjnego oraz jego formuły zobrazowano na rysunku 2, zaś skrócone zbiorcze zestawienie najważniejszych danych z analizowanego projektu przedstawiono w kolejnych punktach artykułu.

\section{Przebieg badania}

W autorskiej metodzie, na podstawie której wykonano zaprezentowane w artykule badania, założono, że pierwszym zasadniczym krokiem jest rozpoznanie aktualnego etapu oraz formuły badanej inwestycji. Kolejnym krokiem była szczegółowa kwerenda dostępnych materiałów. Dotyczyła ona zarówno materiałów z etapu przetargu (specyfikacja istotnych warunków zamówienia - SIWZ, opis przedmiotu zamówienia - OPZ, dokumentów środowiskowych itp.), jak i dokumentacji projektowej. Przegląd dokumentacji jest zwyczajowo pierwszym etapem w procesie identyfikacji ryzyka. Eksperci analizując plany i założenia projektu, doszukują się potencjalnych zagrożeń. Poszczególne etapy wykonanych badań dla przykładowego obiektu przedstawiono w następujących 10 krokach.

I. Rozpoznanie etapu przedsięwzięcia. $\mathrm{W}$ trakcie badania inwestycja jest w etapie realizacji.

II. Rozpoznanie formuły przedsięwzięcia. Inwestycja jest realizowana w formule „projektuj i buduj”.

III. Kwerenda materiałów. Analizie zostały poddane następujące dokumenty: komplet dokumentów z etapu procedury przetargowej (SIWZ, OPZ, koncepcja projektowa itp.), dokumentacja projektowa z etapu realizacji (koncepcja projektowa, projekt budowlany, projekt wykonawczy), pozwolenia na budowę (29 szt.), pozwolenia na rozbiórkę (20 szt.), korespondencja kontraktowa (ponad 12000 pism), roszczenia stron kontraktu (ponad 50 zgłoszeń).

IV. Burza mózgów (metoda heurystyczna). Została ona przeprowadzona po dokonanej kwerendzie dokumentacji kontraktowej. Autorzy przeprowadzili dwa niezależne spotkania z grupami ekspertów (kadra kierownicza z wieloletnim doświadczeniem zawodowym na inwestycjach kolejowych). Spotkania 
odbyły się zarówno w formie konsultacji, jak i badania ankietowego (łączna liczba ankiet 112 egzemplarzy). Konsultacje zostały przeprowadzone indywidualnie, a badanie ankietowe grupowo. Ankieta składała się z części ilościowej oraz jakościowej. Dane ilościowe zostały zebrane na podstawie przemyślanego, ustalonego z góry zbioru pytań. Rolą respondentów było wybranie odpowiedzi zgodnej $\mathrm{z}$ ich doświadczeniem zawodowym. W części jakościowej zostały postawione pytania otwarte.

V. Identyfikacja oraz klasyfikacja interesariuszy. Przeprowadzenie badań z udziałem ekspertów z wieloletnim doświadczeniem oraz dokonana w kroku III kwerenda dokumentów kontraktowych pozwoliła zidentyfikować oraz sklasyfikować interesariuszy w następujący sposób:

- interesariusze wewnętrzni, indywidualni:

- inwestor (reprezentowanego przez jednostkę realizującą projekt CRI (Centrum Realizacji Inwestycji),

- zespół oceny projektów inwestycyjnych (ZOPI),

- Kolejowy Ośrodek Dokumentacji Geodezyjnej i Kartograficznej (KODGiK),

- wykonawca,

- inżynier kontraktu,

- projektant,

- użytkownik reprezentowany przez miejscowy zakład linii kolejowych;

- interesariusze zewnętrzni:

- interesariusze indywidualni

o zarząd dróg wojewódzkich (ZDW),

o urząd miejski,

o Polska Grupa Energetyczna (PGE),

o właściciele przyległych nieruchomości,

- interesariusze grupowi

o społeczeństwo,

o partie polityczne,

o media.

VI. Specyfikacja możliwych czynników ryzyka. Specyfikację najważniejszych zidentyfikowanych czynników ryzyka przedstawiono w tabeli 1.

VII. Kwantyfikacja ryzyka. W związku z prowadzonymi badaniami na obiekcie, który był w trakcie realizacji, kwantyfikacja nie została przeprowadzona. Propozycja kwantyfikacji na potrzeby identyfikacji interesariuszy zostanie przedstawiona indywidualnie w innym opracowaniu.

VIII. Macierz wpływu. Macierz wpływu zidentyfikowanych interesariuszy przedstawiono na rysunku 3. Prezentowana macierz przedstawia graficzny układ interesariuszy pogrupowanych według wpływu oraz nastawienia do badanej inwestycji, określonego metodą bonitacyjną według punktacji przedstawionej w tabeli 2.

IX. Zdefiniowanie wpływu zidentyfikowanych zagrożeń ryzyka na bazowy harmonogram inwestycji. Wpływ zidentyfikowanego ryzyka na bazowy harmonogram prac przedstawiono w tabeli 1.

X. Plan zarządzania ryzykiem. (Niniejsze opracowanie nie obejmuje planu zarządzania ryzykiem). 
Kowalski, J., Połoński, M. (2017). Identyfikacja ryzyka wynikającego z wpływu interesariuszy na realizację inwestycji kolejowych w Polsce. Acta Sci. Pol. Architectura, 16 (4), 83-92. doi: 10.22630/ASPA.2017.16.4.08.

Tabela 1. Specyfikacja najważniejszych możliwych czynników ryzyka oraz ich wpływ na bazowy harmonogram prac

Table 1. Specification of the most important possible risk factors and their impact on the baseline work schedule

\begin{tabular}{|c|c|c|c|}
\hline $\begin{array}{c}\text { Klasyfikacja interesariuszy } \\
\text { Classification of } \\
\text { stakeholders }\end{array}$ & $\begin{array}{l}\text { Zidentyfikowani } \\
\text { interesariusze } \\
\text { Identified } \\
\text { stakeholders }\end{array}$ & $\begin{array}{l}\text { Specyfikacja czynników ryzyka } \\
\text { Specification of risk factors }\end{array}$ & $\begin{array}{l}\text { Wpływ na } \\
\text { harmonogram } \\
\text { [dni] } \\
\text { Impact on } \\
\text { schedule } \\
\text { [days] }\end{array}$ \\
\hline \multirow{8}{*}{$\begin{array}{l}\text { Interesariusze wewnętrzni } \\
\text { Internal stakeholders }\end{array}$} & $\begin{array}{l}\text { PKP PLK - Centrum } \\
\text { Realizacji Inwestycji } \\
\text { (CRI) } \\
\text { Polish State Railways } \\
\text { - Investment realization } \\
\text { center }\end{array}$ & $\begin{array}{l}\text { niewłaściwie przygotowana dokumentacja } \\
\text { projektowa } \\
\text { wrongly prepared design documentation } \\
\text { brak oświadczeń zamawiającego zgód właścicieli } \\
\text { infrastruktury na rozbiórkę elementów } \\
\text { budowlanych } \\
\text { no statement of the employer's approval } \\
\text { of infrastructure owners for the demolition } \\
\text { of building elements }\end{array}$ & 30 \\
\hline & $\begin{array}{l}\text { PKP PLK SA (centrala) } \\
\text { Polish State Railways } \\
\text { (central) }\end{array}$ & $\begin{array}{l}\text { przyznawanie wykonawcy znacznie krótszych } \\
\text { zamknięć torowych } \\
\text { granting much shorter track closures } \\
\text { to the contractor }\end{array}$ & 60 \\
\hline & $\begin{array}{l}\text { Kolejowy Ośrodek } \\
\text { Dokumentacji } \\
\text { Geodezyjnej } \\
\text { i Kartograficznej } \\
\text { (KODGiK) } \\
\text { Railway Land Survey } \\
\text { Document and } \\
\text { Cartography Centres }\end{array}$ & $\begin{array}{l}\text { trudności w pozyskaniu mapy do celów } \\
\text { projektowych } \\
\text { difficulties in obtaining maps for designing }\end{array}$ & 243 \\
\hline & $\begin{array}{l}\text { ZOPI - zespół } \\
\text { oceny przedsięwzięć } \\
\text { inwestycyjnych } \\
\text { team for evaluating } \\
\text { investment projects }\end{array}$ & $\begin{array}{l}\text { zatwierdzenia przez zamawiającego w terminie } \\
\text { umownym projektu budowlanego dla badanych } \\
\text { stacji kolejowych } \\
\text { approval of the investor in the contract term } \\
\text { of the construction project for the railway } \\
\text { stations examined }\end{array}$ & 22 \\
\hline & $\begin{array}{l}\text { wykonawca } \\
\text { the contractor }\end{array}$ & - & - \\
\hline & $\begin{array}{l}\text { inżynier kontraktu } \\
\text { the engineer }\end{array}$ & - & - \\
\hline & $\begin{array}{l}\text { projektant } \\
\text { the designer }\end{array}$ & - & - \\
\hline & $\begin{array}{l}\text { użytkownik } \\
\text { user }\end{array}$ & - & - \\
\hline $\begin{array}{l}\text { Interesariusze zewnętrzni } \\
\text { External stakeholders }\end{array}$ & $\begin{array}{l}\text { administracja } \\
\text { publiczna } \\
\text { public administration }\end{array}$ & $\begin{array}{l}\text { utrudnienia związane } \mathrm{z} \text { uzgodnieniem projektu } \\
\text { budowlanego } \\
\text { difficulties with the agreement } \\
\text { of the construction project }\end{array}$ & 113 \\
\hline
\end{tabular}


Tabela 1 - cd.

Table 1 - cont.

\begin{tabular}{|c|c|c|c|}
\hline & \multirow{2}{*}{$\begin{array}{l}\text { zarząd dróg } \\
\text { wojewódzkich (ZDW) } \\
\text { province roads authority }\end{array}$} & $\begin{array}{l}\text { trudności w uzgodnieniu przez zdw projektu } \\
\text { koncepcyjnego tymczasowej organizacji ruchu } \\
\text { na czas budowy tunelu drogowego } \\
\text { difficulties with the agreement of the temporary } \\
\text { project organization of traffic for the construction } \\
\text { of the road tunnel }\end{array}$ & 46 \\
\hline & & $\begin{array}{l}\text { opóźnienie w uzgodnieniu projektu budowlanego } \\
\text { wiaduktu drogowego } \\
\text { delay in agreeing the construction project } \\
\text { of a viaduct road }\end{array}$ & 128 \\
\hline $\begin{array}{l}\text { Interesariusze indywidualni } \\
\text { Individual stakeholders }\end{array}$ & $\begin{array}{l}\text { właściciele terenów } \\
\text { i nieruchomości } \\
\text { sąsiadujących } \\
\mathrm{z} \text { inwestycją } \\
\text { owners of adjacent land } \\
\text { and real estate } \\
\text { with project }\end{array}$ & $\begin{array}{l}\text { protesty przy pozyskiwaniu decyzji lokalizacji } \\
\text { linii kolejowych oraz pozwoleń na budowę } \\
\text { protests in obtaining the decision of the location } \\
\text { of the railway lines and building permits }\end{array}$ & - \\
\hline \multirow{3}{*}{$\begin{array}{l}\text { Interesariusze grupowi } \\
\text { Group stakeholders }\end{array}$} & społeczeństwo - public & - & - \\
\hline & politycy - politicians & - & - \\
\hline & media & - & - \\
\hline
\end{tabular}

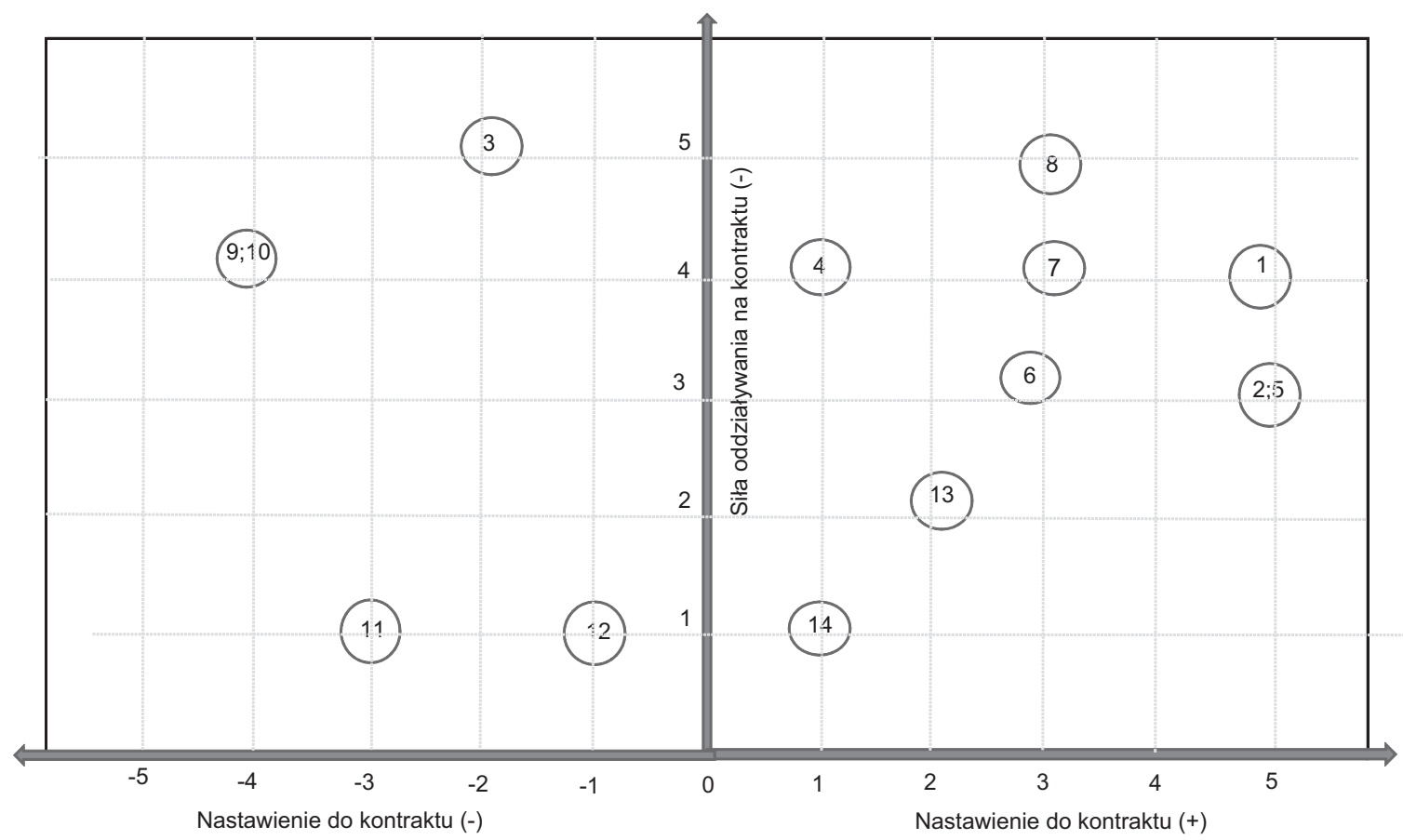

Rys. 3. Macierz wpływu poszczególnych grup interesariuszy na badany kontrakt (według wyników oceny z tab. 2)

Fig. 3. Matrix of impact of individual stakeholder groups on the study contract (according to evaluation results in Table 2) 
Kowalski, J., Połoński, M. (2017). Identyfikacja ryzyka wynikającego z wpływu interesariuszy na realizację inwestycji kolejowych w Polsce. Acta Sci. Pol. Architectura, 16 (4), 83-92. doi: 10.22630/ASPA.2017.16.4.08.

Tabela 2. Wyniki oceny postawy i wpływu interesariuszy na realizowany projekt

Table 2. Evaluation results of attitude towards and impact of stakeholders on realized project

\begin{tabular}{|c|c|c|c|}
\hline $\begin{array}{l}\text { Numer na } \\
\text { macierzy } \\
\text { Number on } \\
\text { the matrix }\end{array}$ & $\begin{array}{l}\text { Interesariusze } \\
\text { Stakeholders }\end{array}$ & $\begin{array}{c}\text { Nastawienia do kontraktu } \\
\text { skala: } \\
-5 \text { - negatywna } \\
0 \text { - obojętna } \\
+5 \text { - pozytywna } \\
\text { Scale setting for contract: } \\
-5 \text { - negative } \\
0 \text { - indifferent } \\
+5 \text { - positive }\end{array}$ & $\begin{array}{c}\text { Wpływ na projekt skala: } \\
0 \text { - nieistotny } \\
5 \text { - istotny } \\
\text { Influence on project scale: } \\
0 \text { - irrelevant } \\
5 \text { - important }\end{array}$ \\
\hline 1 & $\begin{array}{l}\text { PKP PLK S.A. - Centrum Realizacji Inwestycji (CRI) } \\
\text { Polish State Railways - Investment realization center }\end{array}$ & 5 & 4 \\
\hline 2 & $\begin{array}{l}\text { PKP PLK S.A. (Centrala) } \\
\text { Polish State Railways (central) }\end{array}$ & 5 & 3 \\
\hline 3 & $\begin{array}{l}\text { Kolejowy Ośrodek Dokumentacji Geodezyjnej } \\
\text { i Kartograficznej (KODGiK) } \\
\text { Railway Land Survey Document and Cartography } \\
\text { Centres }\end{array}$ & -2 & 5 \\
\hline 4 & $\begin{array}{l}\text { ZOPI - zespół oceny przedsięwzięć inwestycyjnych } \\
\text { team for evaluating investment projects }\end{array}$ & 1 & 4 \\
\hline 5 & wykonawca - the contractor & 5 & 3 \\
\hline 6 & inżynier kontraktu - the engineer & 3 & 3 \\
\hline 7 & projektant - the designer & 4 & 4 \\
\hline 8 & użytkownik - user & 3 & 5 \\
\hline 9 & administracja publiczna public administration & -4 & 4 \\
\hline 10 & $\begin{array}{l}\text { zarząd dróg wojewódzkich (ZDW) } \\
\text { province roads authority }\end{array}$ & -4 & 4 \\
\hline 11 & $\begin{array}{l}\text { właściciele terenów i nieruchomości sąsiadujących } \\
\mathrm{z} \text { inwestycją } \\
\text { owners of adjacent land and real estate with project }\end{array}$ & -3 & 1 \\
\hline 12 & społeczeństwo - public & -1 & 1 \\
\hline 13 & politycy - politicians & 2 & 2 \\
\hline 14 & media & 1 & 1 \\
\hline
\end{tabular}

\section{WNIOSKI}

Biorąc pod uwagę skalę oraz wpływ najważniejszych zidentyfikowanych zagrożeń ze strony poszczególnych interesariuszy można wnioskować, że problem opóźnień na inwestycjach kolejowych realizowanych w Polsce może być zjawiskiem powszechnie występującym. Przedstawione w artykule wyniki badań dotyczą wyłącznie grup ryzyka powiązanych ze zidentyfikowanymi interesariuszami. Wyniki zestawiono tabelarycznie oraz w postaci wykresu macierzy wpływu poszczególnych grup interesariuszy na badany kontrakt (rys. 3). Z wykresu tego można odczytać, która grupa i z jaką siłą wpłynęła na badaną inwestycję. Wnioski z przeprowadzonej analizy 
można próbować ekstrapolować na inne inwestycje, podobne do badanego obiektu. Na szczególną uwagę zasługuje znaczne oddziaływanie Kolejowego Ośrodka Dokumentacji Geodezyjnej i Kartograficznej (KODGiK). Wpływ KODGiK wynikał z konieczności uzgodnienia dokumentacji geodezyjnej (map do celów projektowych), a główny problem dotyczył lokalizacji analizowanego obiektu na obszarach dwóch sąsiednich województw. Powiązanie geodezyjne odrębnych obszarów administracyjnych okazało się trudne ze względu na różną metodykę i techniczne szczegóły opracowania map w regionalnych ośrodkach KODGiK (Połoński i Kowalski, 2017). Dodatkowo uzgadnianie dokumentacji było skomplikowane ze względu na specyfikę wewnętrznych procedur PKP PLK SA.

Kolejnym interesariuszem, którego wpływ na badany kontrakt był znaczny, jest zespół oceny projektów inwestycyjnych (ZOPI). Uzgodnienia z ZOPI, w którego skład wchodzą członkowie bez odpowiednich uprawnień budowlanych, niebędący bezpośrednio odpowiedzialni i związani z realizacją kontraktu, doprowadziły do konieczności ciąłłego uszczegółowiania dokumentacji projektowej i długotrwałych wyjaśnień (Połoński i Kowalski, 2016). W przypadku badanego obiektu wpływ ZOPI i wewnętrznych procedur PKP PLK SA na tryb zatwierdzania dokumentacji projektowej wyniósł 22 dni.

Odziaływanie centrali PKP PLK, jako głównego interesariusza, również było bardzo silne, szczególnie w zakresie przyznawanych wykonawcy krótszych zamknięć torowych. Na badanym obiekcie na 56 wnioskowanych zamknięć, jedynie w 12 przypadkach przyznano wykonawcy czas zamknięcia torowego zgodnie ze złożonym wnioskiem.

Przeprowadzone badania jednoznacznie potwierdzają znaczną siłę oddziaływania interesariuszy na obiekt, a w szczególności na termin jego realizacji. Zgodnie z wynikami przedstawionymi w tabeli 1 łączny wpływ na termin realizacji badanej inwestycji kolejowej przekroczył $500 \mathrm{dni}$ (tzn. ok. 50\% planowanego czasu kontraktu), co wyraźnie wskazuję na potrzebę i użyteczność analizy wpływu poszczególnych grup interesariuszy na przebieg cyklu inwestycyjnego tego typu obiektów. Należy jednak podkreślić, że w przykładzie nie opisano wielu działań, które podjęto, aby zniwelować czy ograniczyć poszczególne grupy ryzyka, a podane w artykule czasy dotyczą wyniku przed tymi działaniami.

Z wykonanych badań i przeglądu literatury (Łukasiewicz, 2012) wynika, że przygotowanie macierzy wpływu interesariuszy należy jednak traktować tylko jako początek procesu zarządzania ryzykiem. Interesariuszy z grupy wpływu i dużego zainteresowania (tzn. w przypadku analizowanego kontraktu, np. użytkownik, administracja publiczna) należy możliwie mocno angażować $\mathrm{w}$ dane przedsięwzięcie oraz podejmować kroki zmierzające do ich pełnego usatysfakcjonowania. Grupy mające duży wpływ, ale małe zainteresowanie wynikami przedsięwzięcia (ZOPI, KODGiK) należy potraktować tak, aby uzyskać ich akceptację, lecz nie narzucać się z nadmiarem informacji. Interesariuszy, którzy są bardzo zainteresowani realizacją danej inwestycji, należy szczegółowo informować o postępach, komunikować się z nimi oraz na bieżąco monitorować problemy, zagrożenia czy konflikty oraz analizować ich przyczyny i cechy. Znaczącą rolę w komunikowaniu się z grupami interesariuszy zewnętrznych może odegrać dobra współpraca z mediami, zwłaszcza lokalnymi. Łukasiewicz (2012) podkreśla również istotę monitorowania interesariuszy, którzy mają mały wpływ i wykazują słabe zainteresowanie realizowanym projektem. W stosunku do nich nie należy narzucać się z nadmierną informacją, jednakże mieć na uwadze, że ich zainteresowanie (a tym samym i wpływ) może ulec zmianie, a zatem nie należy ich lekceważyć, lecz monitorować ich potrzeby i działania.

\section{PODSUMOWANIE}

Celem artykułu jest zobrazowanie znaczenia wpływu różnych grup interesariuszy na przebieg realizacji inwestycji kolejowych w Polsce, próba rozpoznanie czynników ryzyka z nimi związanego oraz ich wpływu na badany obiekt. Na podstawie przeprowadzonej analizy należy stwierdzić, że identyfikacja interesariuszy powinna stać się jednym z fundamentalnych elementów budowania strategii biznesowej planowanych i realizowanych 
przedsięwzięć, w tym kolejowych. Szczególnie dotyczy to obecnego i najbliższego okresu, kiedy znaczne dotacje UE na inwestycje kolejowe na terenach Polski wymagają dobrego przygotowania tych projektów, a tym samym rozpoznania wielu czynników ryzyka związanego z nimi. Realizacja tych inwestycji w wyznaczonych ramach czasowych i założonego budżetu przyniesie wiele korzyści zarówno głównemu beneficjentowi w naszym kraju, PKP S.A., jak również wykonawcom i przyszłym użytkownikom.

Zarządzanie ryzykiem na inwestycjach kolejowych jest tematem bardzo obszernym, podlegającym licznym analizom i bezustannym zmianom, dlatego przedstawione badania należy traktować jako jedną z wielu propozycji pogłębienia i uszczegółowienia tego zagadnienia.

\title{
PIŚMIENNICTWO
}

Forum Kolejowe (2012). Raport z Forum Kolejowego Railway Buisness Forum. Warszawa.

Latawiec, T. (2016). Zmiana modelu realizacji inwestycji kolejowych potrzebna od zaraz. Pobrano z lokalizacji http://www. rynekinfrastruktury.pl/wiadomosci/zmiana-modelu-realizacji-inwestycji-kolejowych-potrzebna-od-zaraz-53472.html.

Łukasiewicz, A. (2012). Interesariusze w przedsięwzięciach infrastruktury drogowej i kolejowej. Studia i Materiaty, 70, 1-90. Warszawa: Instytut Badawczy Dróg i Mostów.

Obłój, K. (1988). Strategia organizacji. Warszawa: PWE.

Office of Govenment Commerce, OGC (2006). Prince 2. Skuteczne zarzadzanie projektami. London.

Połoński, M. i Kowalski, J. (2016). Problemy na etapie uzgadniania dokumentacji projektowej na kontraktach kolejowych z zastosowaniem Warunków Kontraktowych FIDIC. Materiały Budowlane, 6, 162-163. doi: 10.15199/33.2016.06.70.

Połoński, M. i Kowalski, J. (2017). The identification of hazards concerning the character of construction works on railway sites in Poland. Technical Transactions, 5, 47-55. doi: 10.4467/2353737XCT.17.068.6425.

Project Management Institute, PMI (2009). A Guide to the Project Management Body of Knowledge. Wyd. IV, wydanie polskie. Warszawa: Management Training \& Development Center.

Romanyuk, R. (2017). Interesariusz projektu. Pobrano z lokalizacji Encyklopedia zarządzania: https://mfiles.pl/pl/index. php/interesariusze projektu.

\section{INDENTIFICATION OF HAZARDS RELATED WITH THE STAKEHOLDER GROUP DURING RAILWAY INVESTMENTS IN POLAND}

\begin{abstract}
The railway procedure in Poland has a long investment cycle, very complex implementation stages and significant risk factors. It is therefore necessary to improve the level of risk management on planned railway investments. In order to a wider recognition of risk factors, the author of the article presents the method of analysis of stakeholders and the identification of risks associated with them. The risk identification was developed on the basis of the method proposed by the author. The article also presents the strength of the impact of individual stakeholder groups on the subject, including the baseline work schedule. The stakeholder analysis presented in the article points to their significant impact on railway investment and points to the need to take account of their expectations when planning new ventures.
\end{abstract}

Key words: stakeholders, threat identification, risk, railway investments, planning of construction works 